\title{
Caring ability, burden, stress and coping of family caregivers of people in cancer treatment
}

\author{
Habilidade de cuidado, sobrecarga, estresse e coping de cuidadores familiares de pessoas em tratamento oncológico
}

Habilidad de cuidado, sobrecarga, estrés y afrontamiento de los cuidadores familiares de personas en tratamiento oncológico

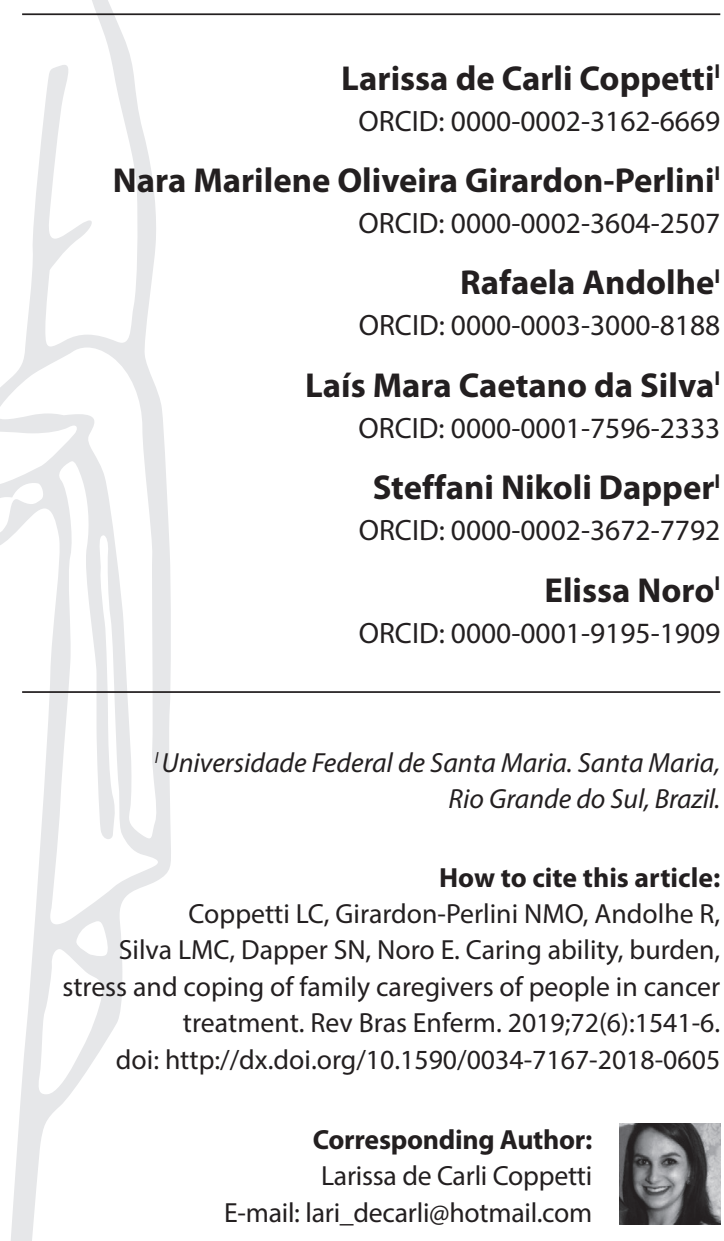

Submission: $02-05-2019$

Approval: 04-07-2019

\begin{abstract}
Objective: To analyze the association between the caring ability and the burden, stress and coping of family caregivers of people in cancer treatment. Method: A crosssectional study with 132 family caregivers. The following instruments were applied: a characterization instrument, the Caring Ability Inventory, the Zarit Burden Interview, the Perceived Stress Scale, and the Brief COPE. The Spearman Correlation was used with significance $\leq 5 \%$. Results: There were significant and positive correlations between total caring ability and: burden - interpersonal relationship $(p=0.03)$; stress $(p=0.02)$ and maladaptive coping $(p=0.00)$; and inversely proportional correlations with problemfocused coping $(p=0.03)$. The courage had inversely proportional correlation with: selfefficacy $(p=0.03)$, interpersonal relationship $(p=0.00)$, stress $(p=0.04)$ and maladaptive coping $(p=0.00)$. The knowledge had significant and positive correlation with problemfocused coping $(p=0.00)$, adaptive coping $(p=0.01)$, and inverse correlation with stress $(p=0.02)$. Conclusion: The level of caring ability correlates with levels of stress and burden, and with the type of coping strategy used by family caregivers.

Descriptors: Caregivers; Home Care; Oncology; Nursing; Psychological Stress.
\end{abstract}

\section{RESUMO}

Objetivo: Analisar a associação entre habilidade de cuidado e sobrecarga, estresse e coping de cuidadores familiares de pessoas em tratamento oncológico. Método: Estudo transversal com 132 cuidadores familiares. Foram aplicados o instrumento de caracterização, o Caring Ability Inventory, a Escala de sobrecarga de Zarit, a Escala de estresse percebido e COPE Breve. Utilizou-se a Correlação de Spearman com significância $\leq 5 \%$. Resultados: Houve correlações significativas e positivas entre habilidade de cuidado total e: sobrecarga relação interpessoal $(p=0,03)$; estresse $(p=0,02)$ e coping desadaptativo $p=0,00)$; e correlação inversamente proporcional com coping focado no problema $(p=0,03)$. A coragem teve correlação inversamente proporcional com: autoeficácia $(p=0,03)$, relacionamento interpessoal $(p=0,00)$, estresse $(p=0,04)$ e coping desadaptativo $(p=0,00)$. $O$ conhecimento teve correlação positiva e significativa com coping focado no problema $(p=0,00)$, coping adaptativo $(p=0,01)$, e correlação inversa com estresse $(p=0,02)$. Conclusão: $o$ nível de habilidade de cuidado tem correlação com os níveis de sobrecarga e estresse, e com o tipo de estratégia de enfrentamento utilizada pelos cuidadores familiares.

Descritores: Cuidadores; Assistência Domiciliar; Oncologia; Enfermagem; Estresse Psicológico.

\section{RESUMEN}

Objetivo: Analizar la asociación entre habilidad de cuidado y sobrecarga, estrés y afrontamiento de cuidadores familiares de personas en tratamiento oncológico. Método: Un estudio transversal con 132 cuidadores familiares. Se aplicaron los siguientes instrumentos: un instrumento de caracterización, el Caring Ability Inventory, el Cuestionario de Zarit, la Escala de Estrés Percibido y el Brief COPE. Se utilizó la correlación de Spearman con un nivel de significación $\leq 5 \%$. Resultados: Hubo correlaciones significativas y positivas entre la habilidad total de cuidado $y$ : sobrecarga - relación interpersonal $(p=0.03)$; estrés $(p=0,02)$ y afrontamiento maladaptativo $(p=0,00)$; $y$ correlaciones inversamente proporcionales con el afrontamiento centrado en el problema $(p=0.03$ ). El coraje tuvo una correlación inversamente proporcional con: autoeficacia $(p=0.03)$, relación interpersonal $(p=0.00)$, estrés $(p=0.04)$ y afrontamiento maladaptativo $(p=0.00)$. El conocimiento tuvo una correlación significativa y positiva con el afrontamiento centrado en el problema $(\mathrm{p}=0,00)$, el afrontamiento adaptativo $(p=0,01)$ y una correlación inversa con el estrés $(p=0,02)$. Conclusión: El nivel de habilidad de cuidado se correlaciona con los niveles de estrés y sobrecarga, y con el tipo de estrategia de afrontamiento utilizada por los cuidadores familiares.

Descriptores: Cuidadores; Atención Domiciliaria de Salud; Oncología; Enfermería; Estrés Psicológico. 


\section{INTRODUCTION}

The current Brazilian scenario presents important changes in the demographic pattern and morbidity and mortality profile of the population with a decline in infectious diseases and an increase in noncommunicable chronic diseases $(\mathrm{NCDs})^{(1)}$. Cancer is one of the DCNTs of higher cost impact at global and national health levels. Data on a global scale report that around the world, about 18 million people get sick from cancer every year ${ }^{(2)}$. In Brazil, is estimated the occurrence of 1,200,000 new cases of cancer for the biennium 2018-2019(1).

In addition to the high global morbidity and mortality rates, in Brazil, cancer is associated with premature death and loss of quality of life caused by sequelae and disability ${ }^{(3)}$. Hence the need for alternative measures, such as home care with a view to meeting the health needs of the population with functional losses and dependence to perform activities of daily living. Home care contributes to the humanization of health care because it involves people in care, and encourages the active participation of subjects and their family in the health-disease-care process ${ }^{(4)}$.

When caring for the dependent person, the family assumes an important role because they are the main source of support. Cancer diagnosis and the changes arising from the reality of care sometimes disorganize the family system and require changes in order to include the treatment demands in the daily routine ${ }^{(5)}$. Although the disease affects the whole family, the care responsibility is usually focused on one of its members, the primary caregiver. The caring activity is often assumed suddenly with little guidance and no previous preparation, which can compromise the quality of care and result in physical and emotional changes in the caregiver ${ }^{(6)}$.

The care should be performed along with supportive actions, especially from nursing professionals with the purpose of guiding the specific knowledge of care and developing or improving the skills. The caring ability is the potential of the person who assumes the role of primary caregiver of a family member or significant person in a disabling disease condition. This ability includes cognitive, instrumental, and attitudinal dimensions that can be identified and measured according to indicators of knowledge, courage, and patience ${ }^{(7)}$.

The effects of caring and the state of vulnerability to which the caregiver is exposed can cause physical, psychological and/or social exhaustion and, consequently, generate negative feelings favorable to the onset of stress and burden ${ }^{(8)}$. Caregivers should be the focus in the care process, given their exposure to the burden resulting from attributions with the dependent family member ${ }^{(9)}$. In turn, this brings the need for coping strategies that may interfere with caregivers' caring ability and quality of life.

The evaluation of the caring ability of family caregivers is an incipient issue in Brazil. A search of online databases was performed to conduct this study, and were found international studies evaluating the caring ability of caregivers with focus on family caregivers. A gap in knowledge was identified because only one study addressed the theme of "caring ability" with informal caregivers, but it was focused on the cultural adaptation of the instrument to measure it, and not on its evaluation and association with burden, stress and coping of family caregivers. Furthermore, the results of the present study may support institutional care policies for caregivers, guide practical nursing activities, and contribute to the planning and adoption of effective intervention strategies for the guidance and preparation of family caregivers.

In view of the above, emerges the following question: is there an association between the caring ability and the burden, stress and coping of family caregivers of patients in cancer treatment? The study hypothesis was that the level of caring ability correlates inversely with levels of burden and stress, and in a directly proportional form with the type of coping strategy used by family caregivers.

\section{OBJECTIVE}

To analyze the association between the caring ability and the burden, stress and coping of family caregivers of people in cancer treatment.

\section{METHOD}

\section{Ethical aspects}

The study followed the recommendations of Resolution $466 / 2012$ of the National Health Council and was analyzed and approved by the Research Ethics Committee of the Universidade Federal de Santa Maria (UFSM).

\section{Design, place of study and period}

A cross-sectional study conducted from March to August 2017 in the chemotherapy and radiotherapy sectors of a university hospital in the central region of the state of Rio Grande do Sul.

\section{Sample: inclusion and exclusion criteria}

The sample consisted of family caregivers of patients in cancer treatment. For the selection of participants, first, patients in cancer treatment with some degree of dependence were identified. Then, caregivers were approached by considering the following inclusion criteria: to be the primary caregiver of a person in cancer treatment with some degree of dependence on activities of daily life; aged 18 years or older; and to provide home-based care for the dependent family member. The exclusion criterion was to present evident cognitive difficulties in the initial approach.

The selection of participants was by the non-probabilistic method and by convenience. During the data collection period, 167 dependent individuals were under treatment, but when approaching their caregivers, 23 were not the main caregivers, five showed communication and/or understanding difficulties, two were under 18 years of age and five did not accept to participate in the study. Thus, the sample consisted of 132 family caregivers, which represented $79.0 \%$ of the population of dependent people in cancer treatment during this period.

\section{Study protocol}

After identification of the dependent patients, was made the first contact with the family member who accompanied them in order to confirm the inclusion criteria. The primary caregiver was the family member with all or part of the responsibility for the 
care of the sick individual. In cases with more than one caregiver, when they mentioned sharing care tasks, patients themselves were asked about who they considered as their primary caregiver, and their indication was respected.

The first approximation was informal and held in the outpatient waiting room, when the detailed proposal of the study was presented verbally with explanations. At this meeting, was made the official invitation to voluntary participate in the study. After acceptance, started the data collection.

Data were collected by applying the following: a questionnaire for the sociodemographic characterization of the family caregiver and for characterization of the care provided; the Brazilian version of the Caring Ability Inventory (CAI-BR); the Zarit Burden Interview (ZBI); the Perceived Stress Scale; and the Brief COPE. The inventory used to measure Caring Ability maintained the original name in English and the acronym "CAI-BR" after adaptation and cross-cultural translation into Brazilian Portuguese, according to recommendation of the responsible authors ${ }^{(10)}$.

The CAI-BR originates from the Caring Ability Inventory (CAI), created in $1990^{(7)}$. Its objective is to evaluate a subject's ability to provide adequate care based on his/her own perception by considering instrumental and cognitive aspects. It consists of 37 items divided into three dimensions: knowledge, courage and patience with 14, 13 and 10 items, respectively. Responses are organized on a Likert scale, ranging from 1-5, in which 1 is "strongly disagree" and 5 is "strongly agree". The answers to items are added in order to reach a total score, and a score for each subscale.

The Cronbach's alpha of the original instrument, CAl, was $0.84^{(7)}$. The Spanish version reached a value of $0.86^{(11)}$ and the value for the Portuguese version was $0.78^{(10)}$. In the present investigation, the Cronbach's alpha value for total CAI-BR was 0.60 .

The Zarit Burden Interview allows assessing the objective and subjective burden of the informal caregiver. It is composed of 22 items evaluated through a Likert scale ranging from zero to four points. By adding the scores is obtained the total score ranging from 0 to 88 with the following classification: <20: no burden; 21-40: mild to moderate burden; 41-60: moderate to severe burden; > 60: severe burden ${ }^{(12)}$. The subjective burden is also assessed, which includes four factors, namely: impact of care delivery; interpersonal relationship; expectation regarding care; perception of self-efficacy. The translated and validated version into Portuguese obtained a Cronbach's alpha of $0.93^{(12)}$ and, in the present study, the internal consistency was 0.84 .

The Perceived Stress Scale was originally developed in 1983 and validated for the Portuguese language in $2007^{(13)}$. It consists of 14 items, seven with positive connotation and seven with negative connotation. Answers are organized in a 0-5 points Likert scale. For positive connotation questions, scores are reversed, and negative connotation questions should be added directly. For the classification of stress level as low, moderate and high, was used the standardization of the scale, in which data arranged in the ordinal scale are transformed into a ratio scale of 0 to $100 \%$, and classified in three categories. The standardization occurred as follows: high for averages between $66.68 \%$ and $100 \%$; moderate for averages between $33.34 \%$ and $66.67 \%$; and low for averages between 0 and $33.33 \%{ }^{(14)}$.

The internal consistency of the original scale obtained a value of 0.77 , and the value for the translated and validated version into
Brazilian Portuguese was $0.62^{(13)}$. In this study, the Cronbach's Alpha value for internal consistency was 0.90 .

The Brief COPE is an instrument resulting from the COPE Inventory that was translated and validated for the Brazilian population in $2012^{(15)}$. It contains 28 items evaluated by a Likert scale ranging from one to four, where $1=$ I haven't been doing this at all, and $4=$ I've been doing this a lot, and respondents can report what they usually do to cope with the stressor. The scores are added, and the higher the score the greater the use of a particular coping strategy. The final score of the scale points to a profile based on the more or less used subscales. The type of coping used can be classified as problem-focused or emotion-focused and subdivided into adaptive or maladaptive ${ }^{(15)}$.

The internal consistency of the validated and translated version for Brazil of the Brief COPE scale measured through the Cronbach's Alpha was $0.84^{(15)}$. In the present study, the value was 0.71 .

The research instruments were applied through individual interviews of the responsible researchers with family caregivers, without the presence of patients, in the nurse's room or other available space in the sectors, in the absence of noises and interferences, and the privacy of participants was guaranteed.

\section{Analysis of results and statistics}

Data were organized and typed concomitantly with the data collection period by two independent typists in an Excel for Windows spreadsheet. After checking and correcting inconsistencies, the information was analyzed electronically with use of the SPSS software version 23.0.

Qualitative variables were presented by distribution of absolute and relative frequencies, and quantitative variables in measures of central tendency, SD (Standard Deviation) and variability. The normality of groups was tested using the Kolmogorov-Smirnov test. The association was assessed through the Spearman Correlation Coefficient, and the significance level adopted was $\leq 5 \%$.

\section{RESULTS}

Regarding the characterization of study participants, there was predominance of women $(n=103 ; 78.0 \%)$, aged between 18 and 76 years $(M=48.68 ; S D=14.01)$, with partner $(n=101 ; 76.5 \%)$, educational level between zero and 20 years, average of 9.08 years of study $(S D=4.61)$, which represents complete primary education. The time under care was 10.18 months ( $S D=14.79)$, on average. Most caregivers had assistance with care $(n=88 ; 66.7 \%)$.

In Table 1, is demonstrated the descriptive analysis of the scores obtained in the CAI-BR, the Zarit Burden Interview, the Perceived Stress Scale and the Brief COPE.

In relation to the classification of levels of ability, family caregivers had a moderate level of ability, both in the total CAI-BR $(n=89$; $67.42 \%)$, and in its dimensions of knowledge ( $n=87 ; 65.91 \%)$, courage $(n=91 ; 68.94 \%)$ and patience $(n=100 ; 75.76 \%)$.

In the application of the Zarit Burden Interview, predominated caregivers with no burden (50.8\%). Among the others, 53 (40.1\%) presented mild to moderate burden and $12(9.1 \%)$ had moderate to severe burden. The subjective burden showed greater influence of the factor impact of care delivery ( $M=8.98$; SD 7.95). 
Table 1 - Descriptive analysis of scores obtained in the instruments used in the study, Rio Grande do Sul, Brazil, 2017

\begin{tabular}{|c|c|c|c|c|}
\hline Variable & & Mean (SD) & Median (IQ) & Variation \\
\hline Ability & $\begin{array}{l}\text { Knowledge } \\
\text { Courage } \\
\text { Patience } \\
\text { Total CAI-BR }\end{array}$ & $\begin{array}{c}52.2(3.54) \\
46.31(3.98) \\
40.54(2.71) \\
139.05(7.1)\end{array}$ & $\begin{array}{c}53(17) \\
46(20) \\
40(14) \\
139(35)\end{array}$ & $\begin{array}{c}44-61 \\
37-57 \\
34-48 \\
125-160\end{array}$ \\
\hline Burden & $\begin{array}{l}\text { Impact of care delivery } \\
\text { Perception of self-efficacy } \\
\text { Expectation regarding care } \\
\text { Interpersonal relationship } \\
\text { Total burden } \\
\text { Stress }\end{array}$ & $\begin{array}{c}8.98(7.95) \\
2.85(2.25) \\
8.95(3.14) \\
1.91(2.17) \\
22.69(11.76) \\
21.43(10.45)\end{array}$ & $\begin{array}{l}7(35) \\
3(8) \\
9(14) \\
2(12) \\
20(55) \\
21(49)\end{array}$ & $\begin{array}{c}0-35 \\
0-8 \\
2-16 \\
0-12 \\
4-59 \\
3-52\end{array}$ \\
\hline Coping & $\begin{array}{l}\text { Problem-focused } \\
\text { Emotion-focused adaptative } \\
\text { Emotion-focused maladaptive }\end{array}$ & $\begin{array}{l}37.88(5.88) \\
14.11(2.66) \\
10.74(3.09)\end{array}$ & $\begin{array}{l}39(30) \\
14(15) \\
10(12)\end{array}$ & $\begin{array}{l}18-48 \\
6-21 \\
8-20\end{array}$ \\
\hline
\end{tabular}

Note: SD-Standard deviation; IQR-Interquartile range.

Table 2 - Correlation analysis (Spearman correlation coefficient) of total caring ability and its dimensions with burden and its factors, stress and coping strategies, Rio Grande do Sul, Brazil, 2017

\begin{tabular}{|c|c|c|c|c|c|c|c|c|c|c|c|c|c|c|c|c|c|c|}
\hline \multirow[t]{2}{*}{ Caring ability } & \multicolumn{2}{|c|}{ Burden } & \multicolumn{2}{|c|}{$\begin{array}{l}\text { Impact of care } \\
\text { delivery }\end{array}$} & \multicolumn{2}{|c|}{$\begin{array}{l}\text { Perception of } \\
\text { self-efficacy }\end{array}$} & \multicolumn{2}{|c|}{$\begin{array}{l}\text { Expectation } \\
\text { regarding care }\end{array}$} & \multicolumn{2}{|c|}{$\begin{array}{l}\text { Interpersonal } \\
\text { relationship }\end{array}$} & \multicolumn{2}{|c|}{ Stress } & \multicolumn{2}{|c|}{$\begin{array}{l}\text { Problem- } \\
\text { focused } \\
\text { coping }\end{array}$} & \multicolumn{2}{|c|}{$\begin{array}{l}\text { Emotion- } \\
\text { focused } \\
\text { adaptative } \\
\text { coping }\end{array}$} & \multicolumn{2}{|c|}{$\begin{array}{c}\text { Emotion- } \\
\text { focused } \\
\text { maladaptive } \\
\text { coping }\end{array}$} \\
\hline & $\mathbf{r}$ & $\mathbf{p}$ & $\mathbf{r}$ & $\mathbf{p}$ & $\mathbf{r}$ & $\mathbf{p}$ & $\mathbf{r}$ & $\mathbf{p}$ & $\mathbf{r}$ & $\mathbf{p}$ & $\mathbf{r}$ & $\mathbf{p}$ & $\mathbf{r}$ & $\mathbf{p}$ & $\mathbf{r}$ & $\mathbf{p}$ & $\mathbf{r}$ & $\mathbf{p}$ \\
\hline Total CAI-BR & -0.14 & 0.10 & -0.13 & 0.12 & -0.07 & 0.42 & -0.06 & 0.49 & -0.18 & $0.03^{*}$ & -0.20 & $0.02^{*}$ & 0.19 & $0.03^{*}$ & 0.06 & 0.45 & -0.23 & $0.00^{*}$ \\
\hline Knowledge & -0.10 & 0.24 & -0.09 & 0.29 & 0.00 & 0.95 & -0.13 & 0.12 & -0.05 & 0.54 & -0.19 & $0.02^{*}$ & 0.26 & $0.00^{*}$ & 0.22 & $0.01^{*}$ & -0.15 & 0.07 \\
\hline Courage & -0.16 & 0.06 & -0.09 & 0.25 & -0.18 & $0.03^{*}$ & -0.04 & 0.58 & -0.22 & $0.00^{*}$ & -0.17 & $0.04^{*}$ & 0.04 & 0.61 & -0.02 & 0.75 & -0.29 & $0.00^{*}$ \\
\hline Patience & -0.01 & 0.83 & -0.04 & 0.61 & 0.00 & 0.97 & 0.05 & 0.57 & -0.07 & 0.41 & 0.02 & 0.79 & 0.00 & 0.99 & -0.10 & 0.22 & 0.05 & 0.51 \\
\hline
\end{tabular}

Concerning classifications of perceived stress levels, the moderate level $(n=61 ; 46.21 \%)$ predominated, followed by the high level $(n=59 ; 44.70 \%)$ and low level ( $n=12 ; 9.09 \%)$. Among the coping strategies used by family caregivers participating in this study, the problem-focused strategies prevailed $(M=37.88 ; S D=5.88)$.

As shown in Table 2, the total ability and the courage dimension are correlated with the burden in the interpersonal relationship factor $(p=0.03, p=0.00)$ of the caregiver with the person cared for. The greater the burden associated with this factor the lesser the family caregiver's caring ability and courage. There is also a statistically significant and negative correlation between courage and burden in the factor of perception of self-efficacy ( $p=0.03)$, where the higher the burden in this factor the lesser the courage.

Between perceived stress and the caring ability, there was a statistically significant and negative correlation between total caring ability and the dimensions of knowledge $(p=0.02)$ and courage $(p=0.02)$. This demonstrates that the higher the perceived stress of the family caregiver the lesser will be their total caring ability, their knowledge and courage (Table 2).

Among coping strategies, there was a statistically significant correlation between the total caring ability and the dimension of knowledge with problem-focused strategies $(p=0.03, p=0.00)$. The greater the caregivers' use of this type of coping the greater will be their total ability and their knowledge. Emotion-focused adaptive coping had a statistically significant correlation with the knowledge dimension $(p=0.01)$, therefore, the greater the caregiver's knowledge the greater the adoption of these actions. Emotion-focused maladaptive coping had a statistically significant and negative correlation with the total caring ability $(p=0.00)$ and the courage dimension $(p=0.00)$. This demonstrated that the greater the use of these strategies the lesser the total ability and the courage of the caregiver (Table 2).

\section{DISCUSSION}

Since this topic has been studied scarcely at the national level, the caring ability represents a gap in Brazilian scientific knowledge. In international studies developed mainly in Colombia, the results obtained on the evaluation of the caring ability identified high levels in the dimensions of knowledge and patience, and moderate levels in the courage dimension ${ }^{(16-17)}$. In this study, the averages observed were lower than those previously mentioned in the knowledge and patience dimensions. This result may be related to the specific characteristics of services where studies were conducted, since Colombia offers programs of preparation and support to family caregivers given by health professionals in order to develop or improve their caring ability.

The burden was absent in $50.8 \%$ of caregivers, and this result is in in line with studies that addressed this theme ${ }^{(16,18)}$. This finding may be related to the presence of help with care that was reported by $66.7 \%$ of caregivers interviewed. Similar results are found in the literature, where support provided by close people, institutions and/or health professionals to family caregivers is considered important to minimize the burden ${ }^{(19)}$.

Even though the mild to moderate or moderate to severe burden affected a lower proportion of participants $(40.1 \%$ and $9.1 \%$, respectively), it should be taken into account given its influence in the performance and ability to care. There was a 
significant relationship between the burden related to the factor of perception of self-efficacy with the dimension of courage, and of the interpersonal relationship with the total caring ability and courage.

Confidence in the growth of the other and in one's own caring ability is what makes caregivers have the courage to face the unknown together with the judgement of their past experiences and their sensitivity to the present moment ${ }^{(20)}$. This may justify the findings of this study, because inter-relational difficulties of caregivers with individuals cared for, added to the feeling of dissatisfaction with their own performance in the practice of care may negatively influence their ability to trust the other and dive into the unknown, that is, will diminish their courage and consequently, their total caring ability.

Likewise, the presence of high levels of stress - evidenced in this study and similar to a study performed with family caregivers of people in home hospitalization ${ }^{(21)}$ - is significantly associated with the dimensions of knowledge and courage, and with the total caring ability. Stress can develop as a result of the person's need to deal with external factors to the organism. In this case, with the dependency of their family member and the demands of care, or with internal conditions related to feelings of anxiety, pessimism and insecurity ${ }^{(22)}$. The stress state can have physical and psychological consequences for caregivers, affect their ability to understand the dependent person's needs, and provide appropriate responses. Such factors diminish the caregivers' knowledge of the other and themselves, their courage to face adversities, and their total caring ability.

Stress requires the individual's response to the stressor, which, after evaluation, determines the choice of the best strategy to be adopted. In the present study, prevailed the problem-focused strategies. They are focused on the individual's reality and linked with the acceptance of responsibility and the planning of problemsolving related to the environment or to the own person ${ }^{(22)}$. In a study with caregivers of dependent elderly people were found similar results ${ }^{(23)}$.

In the search for minimizing the stressor, the type of strategy adopted by family caregivers can influence their caring ability. Problem-focused strategies had a significant relation with the total caring ability and the knowledge dimension. In the effort to adapt to the stressor, family caregivers, through actions focused on the problem, increase their perception about the needs of the other and their own needs, which favors the attributes of knowledge and caring ability.

Knowledge is favored by emotion-focused adaptive strategies, which refer to essential actions for psychological adaptation, as caregivers accept and get used to unchanging conditions and situations, such as the cancer disease and dependency of the family member. On the other hand, there is a negative influence of emotion-focused maladaptative coping on the total caring ability and courage dimension. By developing maladaptive strategies, which include denial and blame, caregivers reduce their ability to face situations imposed by care, the courage to expose themselves to the unknown, and the total caring ability.

The family, especially the primary caregivers of people in cancer treatment, are considered as essential support and the necessary link between patients, family members and the health care team. Sometimes, doubts about the family member's health status, lack of guidance and social support, and caregivers' own experience with the dependent person can cause physical and psychological changes ${ }^{(24)}$. These aspects demand a sensitive and active attitude of health professionals, especially of nursing, in the face of evidences offered.

\section{Limitations of the study}

The limitations of this study are related to the context of access to participants, who are linked to a public service specialized in oncology, and this restricts the generalization of results. Moreover, as this is a cross-sectional study, there is the bias of temporality.

\section{Contributions to the area of nursing and health}

The evidences demonstrated in this study contribute to nursing in the development of a care protocol directed to family caregivers. The caring ability is an incipient thematic in Brazilian studies, and allows knowing the conditions of individuals in order to assume the demands of care. From this point, subsidies can be provided for the nursing practice in the development of knowledge, courage and patience. Supporting actions and guidelines for strengthening family caregivers for home care can minimize the burden and stress, and favor the development of effective coping strategies in order that such adversities do not interfere negatively with the caring ability.

In this context, professional nurses are responsible for identifying the emerging needs of this population. Based on the articulation with other professional groups and levels of health care, they can plan strategies to support caregivers, including actions of health education and psychological support for the promotion of adequate care and quality of life of caregivers living the process of home care.

\section{CONCLUSION}

The results of the study confirm the hypothesis raised initially, and demonstrate the correlation of the level of caring ability with the levels of burden and stress, and with the type of coping strategy used by family caregivers. In spite of the burden in the dimension of interpersonal relationships, family caregivers' caring ability is greater when there is greater courage and less stress. When caregivers use problem-focused strategies or emotionfocused adaptive coping, they can adapt to the caregiver role.

The small number of Brazilian studies that evaluate the caring ability of family caregivers demonstrates the need to develop national studies that evaluate the caring ability, burden, stress and coping of family caregivers. With these studies, it will be possible to know the reality of the country, build a diagnosis close to the real needs of this population at the local, regional and national levels, and direct actions to cope with such situations.

\section{FUNDING}

This study was conducted with the support of the Coordination of Improvement of Higher Education Personnel - Brazil (Portuguese acronym: CAPES) - Financing Code 001. 


\section{REFERENCES}

1. Ministério da Saúde (BR). Instituto Nacional de Câncer José Alencar Gomes da Silva (INCA). Estimativa 2018: incidência de câncer no Brasil [Internet]. Rio de Janeiro: INCA; 2018[cited 2018 May 31]. Available from: http://www1.inca.gov.br/estimativa/2018/estimativa-2018.pdf

2. World Health Organization. International Agency for Research on Cancer. Cancer Today [Internet]. Lyon: Global Cancer Observatory (GLOBOCAN); 2018 [cited 2019 Feb 02]. Available from: http://gco.iarc.fr/today/online-analysis-pie

3. Malta DC, Stopa SR, Szwarcwald CL, Gomes NL, Silva Jr JB, Reis AAC. Surveillance and monitoring of major chronic diseases in Brazil National Health Survey, 2013. Rev Bras Epidemiol. 2015;18(Suppl2):3-16. doi: 10.1590/1980-5497201500060002

4. Ministério da Saúde (BR). Secretaria de Atenção à Saúde. Departamento de Atenção Básica. Caderno de Atenção Domiciliar - Volume 1 [Internet]. Brasília; 2012 [cited 2018 May 31]. Available from: http://189.28.128.100/dab/docs/geral/cap_2_vol_\%201_diretrizes_para_a_ad_ na_ab_final.pdf

5. Costa TF, Costa KNFM, Martins KP, Fernandes MGM, Brito SS. Burden over family caregivers of elderly people with stroke. Esc Anna Nery. 2015;19(2):350-5. doi: 10.5935/1414-8145.20150048

6. Landeiro MJL, Peres HHC, Martins T. Avaliação das necessidades informacionais dos cuidadores domiciliares. Rev Enferm UFSM. 2015;5(3):486-98. doi: 10.5902/2179769216886.

7. Nkongho N. Caring ability inventory. In: Watson J, editor. Assessing and measuring caring in nursing and health sciences. 2nd ed. New York: Springer; 2009. p. 117-24.

8. Sánchez Martínez RT, Cardona EMM, Gómez-Ortega OR. Intervenciones de enfermería para disminuir la sobrecarga en cuidadores: un estudio piloto. Rev Cuid. 2016;7(1):1171-84. doi: 10.15649/cuidarte.v7i1.251

9. Nunes DP, Brito TRP, Corona LP, Alexandre TS, Duarte YAO. Elderly and caregiver demand: proposal for a care need classification. Rev Bras Enferm [Internet]. 2018;71(suppl 2):844-50. [Thematic Issue: Health of the Elderly] doi: 10.1590/0034-7167-2017-0123

10. Rosanelli CLSP, Silva LMG, Gutiérrez MGR. Cross-cultural adaptation of the Caring Ability Inventory to Portuguese. Acta Paul Enferm. 2016;29(3):347-54. doi: 10.1590/1982-0194201600048

11. Díaz LYB. Confiabilidad y validez de constructo del instrumento "Habilidad de Cuidado de Cuidadores Familiares de Personas que Viven una Situación de Enfermedad Crónica". [Dissertación] [Internet]. Bogotá: Universidad Nacional de Colombia; 2005 [cited 2018 Apr 25]. Available from: http://www.bdigital.unal.edu.co/3806/1/539351.2011.pdf

12. Scazufca M. Brazilian version of the Burden Interview Scale for the assessment of care in carers of people with mental illnesses. Rev Bras Psiquiatr 2002;24(1)12-7. doi: 10.1590/S1516-44462002000100006

13. Luft CDB, Sanches SO, Mazo GZ, Andrade A. Versão brasileira da Escala de Estresse Percebido: tradução e validação para idosos. Rev Saúde Pública. 2007;41(4):606-15. doi: 10.1590/S0034-89102007000400015

14. Lopes LFD. Métodos Quantitativos. Santa Maria: UFSM; 2016.

15. Brasileiro SV. Adaptação transcultural e propriedades psicométricas do COPE breve em uma amostra brasileira [dissertação] [Internet]. Goiânia: Universidade Federal de Goiás; 2012 [cited 2018 Apr 30]. Available from: http://repositorio.bc.ufg.br/tede/handle/tede/3351

16. Díaz CE, Mendoza SP, Carrilo KS. Habilidad de cuidado y nivel de sobrecarga en cuidadoras/es informales de personas dependientes [Internet]. Enferm Glob. 2015 [cited 2018 Apr 30];14(2):235-48. Available from: http://scielo.isciii.es/pdf/eg/v14n38/administracion4.pdf

17. Ostiguín-Meléndez RM, Rivas-Herrera JC, Vallejo-Allende M, Crespo-Knopfler S, Alvarado-Aguilar S. Habilidades del cuidador primario de mujeres mastectomizadas. Invest Educ Enferm [Internet]. 2012 [cited 2018 May 01];30(1):9-17. Available from: http://www.scielo.org.co/ scielo.php?script=sci_arttext\&pid=S0120-53072012000100002

18. Chaparro-Díaz L, Barrera-Ortiz L, Vargas-Rosero E, Carreño-Moreno SP. Mujeres cuidadoras familiares de personas con enfermedad crónica en Colombia. Rev Cienc Cuidad [Internet]. 2016 [cited 2018 Jun 02];13(1):72-86. Available from: https://revistas.ufps.edu.co/index.php/ cienciaycuidado/article/view/736/718

19. Gratão ACM, Talmelli LFS, Figueiredo LC, Rosset I, Freitas CP, Rodrigues RAP. Functional dependency of older individuals and caregiver burden. Rev Esc Enferm USP. 2013;47(1):137-44. doi: 10.1590/S0080-62342013000100017

20. Mayeroff M. A arte de servir ao próximo para servir a si mesmo. Rio de Janeiro: Record; 1971.

21. Nogueira AS, Souza RAAR, Casarin RG. O estresse nos cuidadores de pacientes em internação domiciliar. Rev Cient FAEMA. 2014;5(2):50-64. doi: https://doi.org/10.31072/rcf.v5i2.239

22. Lazarus RS. Psychological stress in the workplace. In.: Crandall R, Perrewé PL, editors. Occupational stress: A handbook. Washington: Taylor \& Francis; 1995. p. 3-14.

23. Rocha BMP, Pacheco JEP. Elderly persons in a situation of dependence: informal caregiver stress and coping. Acta Paul Enferm. 2013;26(1):50-6. doi: 10.1590/S0103-21002013000100009

24. Mónico LSM, Custódio JRA, Frazão AA, Parreira P, Ramos A, Correia S, et al. The family in care for the elderly: managing the overload and coping with difficulties. Rev Iberoam Salúd Envelhec Online. 2018;3(2):899-913. doi: 10.24902/r.riase.2017.3(2).982 